\title{
ANALISIS PEMAHAMAN MATEMATIKA SISWA DITINJAU DARI MINAT BELAJAR PADA MASA PANDEMI COVID-19
}

\author{
Vina Dwi Sri Dewi Ritonga', Roslian Lubis², Nunik Ardiana ${ }^{3}$ \\ Fakultas MIPA Program Studi Pendidikan Matematika \\ Institut Pendidikan Tapanuli Selatan
}

\begin{abstract}
Abstrak
Penelitian ini bertujuan untuk menganalisis pemahaman matematis siswa berdasarkan minat belajar pada masa pandemi Covid-19. Pendekatan penelitian menggunakan penelitian kualitatif. Angket, tes, dan wawancara digunakan dalam pengumpulan data. Teknik analisis data menggunakan reduksi data, penyajian data, dan penarikan kesimpulan. Subjek penelitian ini dikategorikan menjadi 3 bagian yaitu siswa yang memiliki minat belajar tinggi, memiliki minat belajar rata -rata, dan minat belajar rendah. Selanjutnya hasil penelitian menunjukkan (1) siswa yang memiliki minat belajar tinggi memiliki pemahaman matematika yang tinggi, (2) siswa yang memiliki minat belajar rata-rata memiliki pemahaman matematika yang sedang, dan (3) siswa yang memiliki minat belajar rendah memiliki pemahaman matematika yang rendah.
\end{abstract}

Kata kunci : pemahaman matematis, minat belajar siswa, pandemi Covid-19.

\section{Abstract}

This study aimed to analyze students' mathematical comprehension based on learning interest in pandemic Covid-19 period. The approach of the research applied qualitative descriptive. Questionnaire, test, and interview were used in collecting the data. The technique of data analysis used data reduction, presentation of the data, and taking conclusion. Subject of the research was categorized into 3 part includes students who have students' high learning interest, students' average learning interest, and students' low learning interest. Furthermore, the result of the research shows (1) students who have high learning interest have high mathematical comprehension, (2) students who have average learning interest have average mathematical comprehension, and (3) students who have low learning interest have low mathematical comprehension.

Keywords :mathematical comprehension, students' learning interest, pandemic Covid-19.

\section{PENDAHULUAN}

Pendidikan sangat penting dalam menciptakan generasi penerus bangsa yang berkualitas dan memiliki keterampilan.Upaya yang dilakukan untuk mencapai tujuan pendidikan nasional adalah melalai pendidikan di sekolah.Dunia pendidikan khususnya pada mata pelajaran matematika telah menjadi perhatian utama dari berbagai kalangan, hal ini disadari bahwa betapa pentingnya peranan matematika dalam pengembangan berbagai ilmu teknologi dan dalam kehidupan sehari-hari.

Dalam pembelajaran matematika kemampuan pemahaman matematis merupakan salah satu kemampuan yang sangat penting untuk dimiliki siswa dalam belajar matematika.Oleh karena itu untuk mengetahui kemampuan pemahaman matematika perlu digambarkan keterampilan memahami masalah dan menyelesaikan masalah.

Mengingat pentingnya kemampuan pemahaman matematika, siswa didorong dan diberi kesempatan seluas-luasnya untuk berinisiatif dan berpikir sistematis dalam menghadapi suatu masalah dengan menerapkan pengetahuan yang didapat sebelumnya, untuk mengetahui sejauh mana siswa dalam memahami masalah atau memecahkan masalah dapat dilihat dari bagaimana siswa tersebut memahami masalah, membuat rencana penyelesaian masalah, menyelesaikan masalah sesuai rencana, dan memeriksakembali prosedur hasil penyelesaian dengan demikian hendaknya kemampuan pemahaman matematika tersebut menjadi fokus dalam pembelajaran matematika di sekolah. Namun pada kenyataannya, kemampuan pemahaman matematis siswa saat ini masih rendah disebabkan oleh kurangnya minat dalam belajar matematika karena telah terlanjur menganggap matematika adalah pelajaran yang sulit dan rumit.

Minat belajar siswa merupakan salah satu aspek yang diperhatikan dalam pembelajaran matematika. Minat pada dasarnya merupakan perhatian yang bersifat khusus, siswa yang menaruh minat pada suatu mata pelajaran pelajaran perhatiannya akan tinggi dan minatnya berfungsi sebagai pendorong kuat untuk terlihat secara aktif dalam kegiatan belajar mengajar. Minat adalah

Email: vinadwisrid2rtg@gmail.com 
JURNAL MathEdu (Mathematic Education Journal) http://journal.ipts.ac.id/index.php/MathEdu

Vol. 4. No. 3 November 2021

kecenderungan jiwa yang relatif menetap kepada diri seseorang yang biasanya disertai dengan perasaan senang, sedangkan belajar adalah suatu kegiatan yang menimbulkan suatu perubahan tingkah laku yang relatif tetap dan perubahan itu dilakukan lewat usaha yang disengaja.

Pada awal tahun 2020 dunia diresahkan dengan adanya wabah Corona VirusDisease (Covid-19).Corona Virus adalah keluarga besar virus yang menyebabkan penyakit mulai dari gejala ringan sampai berat.Corona Virus Disease (Covid-19) adalah penyakit jenis baru yang belum pernah diidentifikasi sebelumnya pada manusia.Tanda dan gejala umum infeksi Covid-19 antara lain gejala gangguan pernapasan akut seperti demam, batuk dan sesak napas. Masa inkubasi rata-rata 5-6 hari dengan masa inkubasi terpanjang 14 hari. Menurut data gugus tugas percepatan penanganan Covid-19 Republik Indonesia, kasus pertama penyakit ini terjadi di kota Wuhan Cina. Sedangkan di Indonesia mulai berkembang pada awal Maret 2020 dengan jumlah yang bertambah setiap hari yang memakan korban jiwa. Jumlah kasus terkonfirmasi positif hingga 29 januari 2021 adalah 1.051.795 orang, jumlah kematian 29.518 orang, jumlah yang sembuh 852.260 orang. Sudah menyebar di 34 Provinsi dan 510 Kabupaten/Kota.

Akibat adanya virus tersebut, situasi membuat kehidupan menjadi terkendala termasuk aspek pendidikan karena virus tersebut dengan cepat menyebar atau menular dari manusia ke manusia melalui sentuhan ataupun saat bersin maupun batuk. Akibat dari pandemi Covid-19 pendidikan di Indonesia sangat terganggu dalam kegiatan proses belajar mengajar. Dengan adanya pembatasan interaksi, kementerian pendidikan di Indonesia juga mengeluarkan kebijakan proses belajar mengajar tatap muka dihentikan dan mengganti proses kegiatan belajar mengajar menjadi pembelajaran dalam jaringan (daring) dengan memanfaatkan jaringan internet.

Sementara dari hasil wawancara pada tanggal 01 Februari 2021 dengan guru mata pelajaran matematika Ibu Rahmaito Sari Harahap, S.Pd di kelas X MIA-3 SMA Negeri 1 Padang Bolak, menyatakan bahwa kesulitan yang dihadapi pada saat proses belajar mengajar yaitu kurangnya minat siswa dalam belajar matematika karena menganggap matematika adalah pelajaran yang sulit dan rumit. Kemampuan pemahaman siswa mengikuti proses pembelajaran dalam jaringan (daring) juga kurang optimal karena proses belajar dan pembelajaran tidak secara langsung (daring).

\section{METODOLOGI PENELITIAN}

Penelitian ini dilaksanakan di SMA Negeri 1 Padang Bolak yang terletak di Jl. Kihajar Dewantara No.50 Gunungtua.Sekolah ini dipimpin oleh Bapak Parulian, S.Pd sebagai kepala sekolah, adapun tenaga pengajar matematika di kelas X MIA-3 yaitu Ibu Rahmaito Sari Harahap, S.Pd.

Adapun alasan peneliti menjadikan lokasi tersebut sebagai tempat penelitian karena peneliti ingin mengetahui bagaimana gambaran kemampuan pemahaman matematika siswa ditinjau dari minat belajar siswa pada masa pandemi Covid-19 di sekolah tersebut. Waktu yang ditentukan dalam penelitian ini adalah kurang lebih 3 bulan mulai dari Februari sampai April 2021.

Metode penelitian yang digunakan dakalam penelitian ini adalah metode penelitian kualitatif. Adapun karakteristik penelitian kualitatif menurut Sugiyono (2011:15-16) mengemukakan bahwa:

a. Dilakukan pada kondisi yang alamiah, (sebagai lawannya adalah eksperimen), langsung ke sumber data dan peneliti adalah instrumen kunci.

b. Penelitian kualitatif lebih bersifat deskriptif. Data yang terkumpul berbentuk katakata atau gambar, sehingga tidak menekankan pada angka.

c. Penelitian kualitatif lebih menekankan pada proses daripada produk atau outcome.

d. Penelitian kualitatif melakukan analisis data induktif.

e. Penelitian kualitatif lebih menekankan makna (data yang dibalik yang teramati).

Objek penelitian adalah isu, problem, atau permasalahan yang dibahas, dikaji, dan diteliti.Adapun yang menjadi objek penelitian ini adalah kemampuan pemahaman matematika siswa ditinjau dari minat siswa pada masa pandemi Covid-19.

Sedangkan informan penelitian adalah orang yang memberikan informasi tentang objek penelitian yang akan diteliti. Adapun informan dalam penelitian ini yaitu beberapa siswa/siswi kelas X MIA-3 dan guru mata pelajaran matematika SMA Negeri 1 Padang Bolak.

Teknik pengumpulan data adalah langkah-langkah yang dilakukan untuk mengumpulkan data. Menurut Silalahi (2012:291) menyatakan "Metode pengumpulan data adalah cara yang dapat digunakan untuk mengumpulkan atau mendapatkan data dari fenomena empirik". Menurut 
JURNAL MathEdu (Mathematic Education Journal) http://journal.ipts.ac.id/index.php/MathEdu Vol. 4. No. 3 November 2021

Sugiyono (2011:308) "Teknik pengumpulan data merupakan langkah yang paling utama dalam penelitian, karena tujuan utama dari penelitian adalah mendapatkan data". Teknik pengumpulan data yang digunakan dalam penelitian ini adalah dengan menggunakan kuesioner (Angket), tes, dan wawancara.

Tabel 1.Kisi-Kisi Indikator Minat Belajar Siswa

\begin{tabular}{|l|l|c|c|}
\hline No & \multicolumn{1}{|c|}{ Indikator } & $\begin{array}{c}\text { Item } \\
\text { Pernyataan }\end{array}$ & $\begin{array}{c}\text { Banyak } \\
\text { Pertanyaan }\end{array}$ \\
\hline 1 & Rasa Senang & 1,2 & 2 \\
\hline 2 & Ketertarikan & $3,4,5$ & 3 \\
\hline 3 & Perhatian & 6,7 & 2 \\
\hline 4 & Keterlibatan & $8,9,10$ & 3 \\
\hline \multicolumn{2}{|c|}{ Jumlah } & 10 \\
\hline
\end{tabular}

Tabel 2.Penskoran Hasil Angket

\begin{tabular}{|c|c|c|}
\hline Skor & Alternatif Jawaban & Nomor Item \\
\hline 5 & Sangat Setuju (SS) & \multirow{2}{*}{$1,2,3,4,5,6,7,8,9,10$} \\
\hline 4 & Setuju (ST) & \\
\hline 3 & Ragu-ragu (RG) & \\
\hline 2 & Tidak Setuju (TS) & \\
\hline 1 & Sangat Tidak Setuju (STS) & \\
\hline
\end{tabular}

Arikunto (Rambe Nelli 2020:32)

Skor angket mengenai minat belajar siswa diperoleh selanjutnya dikualifikasikan dengan ketentuan sebagaimana tertera pada tabel berikut:

Tabel 3.Kualifikasi Hasil Skor Angket Minat Belajar Matematika Siswa

\begin{tabular}{|c|c|}
\hline Skor Angket & Kategori \\
\hline $80,00 \leq$ Skor $\leq 100$ & Sangat Baik \\
\hline $66,00 \leq$ Skor $\leq 79,99$ & Baik \\
\hline $56,00 \leq$ Skor $\leq 65,99$ & Cukup \\
\hline $40,00 \leq$ Skor $\leq 55,99$ & Kurang \\
\hline $0 \leq$ Skor $\leq 19,99$ & Sangat Kurang \\
\hline
\end{tabular}

Arikunto (Rambe, Nelli 2020:32)

Tabel 4.Kisi-Kisi Kemampuan Pemahaman Matematika Siswa

\begin{tabular}{|l|l|c|c|}
\hline No & \multicolumn{1}{|c|}{ Indikator } & $\begin{array}{c}\text { Item } \\
\text { Pertanyaan }\end{array}$ & $\begin{array}{c}\text { Banyak } \\
\text { Pertanyaan }\end{array}$ \\
\hline 1 & $\begin{array}{l}\text { Memilih prosedur atau operasi tertentu untuk } \\
\text { mengaplikasikannya dalam pemecahan } \\
\text { masalah. }\end{array}$ & \multirow{2}{*}{$1,2,3$} & \\
\hline 2 & Membuat contoh dan bukan contoh. & \\
\hline 3 & Menginterpretasikan suatu konsep. & \\
\hline 4 & Membedakan konsep-konsep. & $\mathbf{3}$ \\
\hline \multicolumn{2}{|c|}{ Jumlah } \\
\hline
\end{tabular}

Tabel 5.Kriteria Penilaian Kemampuan Pemahaman Matematika Siswa

\begin{tabular}{|c|c|c|}
\hline No & Interval & Keterangan \\
\hline 1 & $80-100$ & Tinggi \\
\hline 2 & $50-75$ & Sedang \\
\hline 3 & $0-49$ & Rendah \\
\hline
\end{tabular}

Danar (2016:5)

Keabsahan data dilakukan untuk membuktikan apakah penelitian yang dilakukan benarbenar merupakan penelitian ilmiah sekaligus untuk menguji data yang diperoleh.Menurut Sugiyono (2011:27) mengatakan bahwa "Triangulasi diartikan sebagai teknik pengumpulan data yang bersifat menggabungkan data berbagai teknik pengumpulan data dan sumber data yang telah ada". Menurut Sugiyono (2011:370-371) terdapat tiga macam Triangulasi yaitu: 
JURNAL MathEdu (Mathematic Education Journal) http://journal.ipts.ac.id/index.php/MathEdu

Vol. 4. No. 3 November 2021

1. Triangulasi Sumber untuk menguji kredibilitas data dilakukan dengan cara mengecek data yang diperoleh melalui beberapa sumber.

2. Triangulasi Teknik untuk menguji kredibilitas data dilakukan dengan cara mengecek data kepada sumber yang sama dengan teknik yang berbeda.

3. Triangulasi Waktu dapat dilakukan dengan cara mengecek hasil penelitian, dari tim peneliti lain yang diberi tugas melakukan pengumpulan data.

Dalam penelitian ini, peneliti menggunakan teknik keabsahan data dengan triangulasi teknik. Triangulasi teknik yaitu peneliti menggunakan teknik pengumpulan data yang berbedabeda untuk mendapatkan data dari sumber yang sama.

Analisis data dalam penelitian ini menggunakan model Miles dan Huberman. Menurut Miles dan Huberman (dalam Silalahi 2012:339) mengatakan "Kegiatan analisis terdiri dari tiga alur kegiatan secara bersamaan, yaitu reduksi data, penyajian data, dan penarikan kesimpulan atau verifikasi"

1. Reduksi Data

Reduksi Data adalah penyederhanan, dan membuang data yang tidak perlu sehingga data tersebut dapat menghasilkan informasi. Menurut Sugiyono (2011:337) mengatakan bahwa "Reduksi data merupakan proses berpikir sensitif yang memerlukan kecerdasan dan keluasan serta kedalaman wawasan yang tinggi”.

2. Penyajian Data

Setelah data direduksi langkah selanjutnya adalah mendisplaykan data. Menurut Silalahi (2012:340) mengatakan "Penyajian data yaitu sebagai sekumpulan informasi tersusun yang memberi kemungkinan adanya penarikan kesimpulan dan pengambilan tindakan".

3. Kesimpulan/Verifikasi Data

Langkah selanjutnya analisis data kualitatif adalah penarikan kesimpulan dan verifikasi. Menurut Yaumi dan Damonopolii (2014:145) mengatakan "Penarikan kesimpulan berarti proses penggabungan beberapa penggalan informasi untuk mengambil informasi".

\section{HASIL DAN PEMBAHASAN}

Untuk mempermudah peneliti dalam melakukan analisis data maka peneliti membuat penyajian data dalam bentuk tabel seperti berikut:

Tabel 6. Kesimpulan Analisis Data

\begin{tabular}{|c|c|c|c|c|c|c|c|}
\hline No & Subjek & Soal & $1-1$ & $1-2$ & $1-3$ & $1-4$ & $\begin{array}{c}\text { Minat } \\
\text { Belajar }\end{array}$ \\
\hline \multirow[t]{4}{*}{1} & \multirow{3}{*}{ NAS } & 1 & $\sqrt{ }$ & $\sqrt{ }$ & $\sqrt{ }$ & $\sqrt{ }$ & \multirow{3}{*}{$\begin{array}{c}\text { Sangat } \\
\text { Baik }\end{array}$} \\
\hline & & 2 & $\sqrt{ }$ & $\sqrt{ }$ & $\sqrt{ }$ & $\sqrt{ }$ & \\
\hline & & 3 & $\sqrt{ }$ & $\sqrt{ }$ & $\sqrt{ }$ & $\sqrt{ }$ & \\
\hline & \multicolumn{2}{|c|}{ Kesimpulan } & Mampu & Mampu & Mampu & Mampu & \multirow{5}{*}{ Baik } \\
\hline \multirow[t]{4}{*}{2} & \multirow{3}{*}{$\mathrm{RS}$} & 1 & $\sqrt{ }$ & $\sqrt{ }$ & $\sqrt{ }$ & $\sqrt{ }$ & \\
\hline & & 2 & - & - & - & - & \\
\hline & & 3 & $\sqrt{ }$ & $\sqrt{ }$ & $\sqrt{ }$ & $\sqrt{ }$ & \\
\hline & \multicolumn{2}{|c|}{ Kesimpulan } & Mampu & Mampu & Mampu & Mampu & \\
\hline \multirow[t]{3}{*}{3} & \multirow{3}{*}{ FEH } & 1 & $\sqrt{ }$ & $\sqrt{ }$ & $\sqrt{ }$ & $\sqrt{ }$ & \multirow{4}{*}{ Cukup } \\
\hline & & 2 & - & - & - & - & \\
\hline & & 3 & - & - & - & - & \\
\hline & \multicolumn{2}{|c|}{ Kesimpulan } & $\begin{array}{l}\text { Kurang } \\
\text { Mampu }\end{array}$ & $\begin{array}{l}\text { Kurang } \\
\text { Mampu }\end{array}$ & $\begin{array}{l}\text { Kurang } \\
\text { Mampu }\end{array}$ & $\begin{array}{l}\text { Kurang } \\
\text { Mampu }\end{array}$ & \\
\hline
\end{tabular}

Hasil penelitian yang telah dianalisis peneliti, ditemukan bahwa siswa memiliki kemampuan akademik matematika yang berbeda.Minat merupakan salah satu faktor yang berpengaruh terhadap kemampuan pemahaman siswa dalam mempelajari suatu materi. Minat merupakan alat motivasi utama yang dapat membangkitkan kegairahan siswa dalam rentang waktu tertentu (Natalia, Sri Sulastri,dkk. 2017:108). Siswa yang memiliki minat teradap suatu bidang studi tertentu cenderung tertarik perhatiannya dan dengan demikian timbul motivasinya untuk mempelajari bidang studi tersebut.

Jika suatu hal atau suatu kegiatan diminati seseorang maka akan diperhatikan dengan disertai rasa senang. Jika seseorang tidak berminat pada suatu materi atau topik matematika yang 
sedang dipelajari maka dia akan malas untuk mempelajarinya dan perhatiannya akan kurang terhadap pelajaran. Situasi senang terhadap pelajaran siswa akan lebih mudah dalam mempelajari topik tersebut sehingga hasil belajarnya lebih tinggi. Hal tersebut dapat dilihat dari hasil penelitian, bahwa siswa yang memperoleh nilai tinggi cenderung hasil angket minat belajarnya baik dan sebaliknya siswa yang nilainya rendah hasil angket minat belajarnya pun kurang baik.

Oleh karena itu, dengan adanya minat terhadap mata pelajaran matematika maka siswa akan mempunyai keinginan untuk memahami suatu materi pelajaran. Apabila siswa kurang berminat dalam belajar matematika maka siswa tersebut cenderung akan mengabaikan pelajaran matematika sehingga siswa akan sulit menerima dan memahami materi yang disampaikan dalam pembelajaran dan menurunnya pemahaman siswa.

\section{KESIMPULAN}

\section{Kesimpulan}

Berdasarkan paparan data, temuan penelitian dan pembahasan penelitian yang telah diuraikan maka diperoleh kesimpulan bahwa minat belajar sangat berpengaruh terhadap tingkat kemampuan pemahaman matematika siswa.

Seperti hasil analisis yang diwakilkan oleh 3 siswa yang terambil melalui purpose sampling yaitu kemampuan pemahaman matematika siswa ditinjau dari minat belajar siswa. Subjek NAS hasil tes kemampuan pemahaman tinggi cenderung hasil angket minat belajarnya pun berada pada kategori sangat baik, subjek RS hasil tes kemampuan pemahaman berada pada kategori sedang dan hasil angket minat belajarnya berada paada kategori baik, dan subjek FEH tes kemampuan pemahaman matematika berada pada kategori rendah dan hasil angket belajarnya pun cenderung cukup/kurang.

Oleh karena itu, dengan adanya minat terhadap mata pelajaran matematika maka siswa akan mempunyai keinginan untuk memahami suatu materi pelajaran. Apabila siswa kurang berminat dalam belajar matematika maka siswa tersebut cenderung akan mengabaikan pelajaran matematika sehingga siswa akan sulit menerima dan memahami materi yang disampaikan dalam pembelajaran dan menurunnya pemahaman siswa.

\section{Saran}

Berdasarkan kesimpulan dari penelitian yang diperoleh, maka ada beberapa saran yaitu sebagai berikut: Berdasarkan hasil penelitian ini terlihat bahwa minat belajar siswa dengan pemahaman matematika, dan apabila minat diabaikan dalam belajar maka hasil yang diharapkan tidak maksimal. Oleh karena itu diharapkan sekolah dapat memperhatikan minat belajar siswa agar pemahaman matematika dapat meningkat.Kepada guru agar dalam mengajar harus memperhatikan minat siswa terlebih dahulu dengan membuat model pembelajaran yang menarik agar siswa mempunyai minat pada mata pelajaran matematika.Kepada pembaca sebagai bahan bacaan dan menambah wawasan.

\section{REFERENSI}

Atmojo Danar 2016. Analisis Keterampilan Metakognitif Siswa dalam Menyelesaikan Soal Matematika Geometri Dimensi Dua, Surakarta: Jurnal Publikasi Ilmia Program Studi Pendidikan Matematika Fakultas Keguruan dan Ilmu Pendidikan Universitas Muhammadiyah Surakarta.

Natalia, Sri Sulastri, dkk. 2017. Analisis Tingkat Pemahaman Siswa Berdasarkan Teori APOS Pada Materi Persamaan Kuadrat Ditinjau Dari Minat Belajar Siswa Kelas X SMA Negeri 2 Surakarta Matematika Tahun Ajaran 2015/2016. Jurnal Pendidikan Matematika dan

Rambe, Nelli. 2020. Peningkatan Kemampuan Penalaran Matematis Siswa Melalui Penggunaan Model Problem Posing di SMP Swasta Tapian Nauli. Jurnal Mathedu.Vol.3,No.2 Juli 2020

Silalahi, Ulber. 2012. Metode Penelitian Sosial. Bandung: Refika Aditama.

Sugiyono. 2011. Metode Penelitian Kombinasi (Mixed Methods). Bandung: Alfabeta.

Yaumi, Muhammad dan Damopolii, Muljono. 2014. Action Research Teori, Model, dan Aplikasi. Jakarta: Kencana Prenamedia Group. 